\title{
How Blood Group Influence Hair Texture?
}

\author{
Muhammad Imran Qadir and Safia Bibi* \\ Department of Molecular Biology and Biotechnology, Multan, Pakistan \\ *Corresponding author: Safia Bibi, Department of Molecular Biology and Biotechnology Multan, Pakistan
}

\begin{abstract}
Objective of present studies was to correlates blood grouping with hair texture. Total 181 subjects participated in present study. The subjects were students in Baha Uddin Zakariya University Multan, Pakistan. Blood groups are chemical system used in blood transfusion and determination of parentage. Two types of blood groups are discovered yet, ABO and Rh. A survey was performed among subjects of different blood groups to determine their hair texture. Each subject told either they had curly or straight hair with his consent. It was concluded from present study that females having B+ blood group had maximum straight hair while A- subjects (males and females), B- subjects (males \& females), AB+ males, AB- subjects (males and females), $\mathrm{O}$ - males had minimum curly hair similarly $\mathrm{AB}$ - and $\mathrm{O}$ - males had minimum straight hair.
\end{abstract}

Keywords: Blood Group; Curly Hair; Straight Hair

\section{Introduction}

Blood groups are the complex chemical system that are present on the surface of blood cells. All bloods have the same basic components as red blood cells, white blood cells, platelets and plasma. There are two types of blood group system. ABO blood group and Rh. ABO blood system has four types. $A(A+, A-), B(B+$, $\mathrm{B}-), \mathrm{AB}(\mathrm{AB}+\mathrm{AB}-)$ and $\mathrm{O}(\mathrm{O}+, \mathrm{O}-)$. Blood group $\mathrm{A}$ has antigen $\mathrm{A}$ with anti-B antibodies. Blood group $B$ has $B$ antigen with anti-A antibody. AB blood group has both $A$ and $B$ antigen with no antibodies. Blood group $\mathrm{O}$ has neither $\mathrm{A}$ nor $\mathrm{B}$ antigen but with $\mathrm{A}$ and $\mathrm{B}$ antibodies. It is the most important blood group system for the blood transfusion in humans. 0 blood group individuals are called universal donor while AB blood group individual are called universal recipients [1]. Another type of blood group system is Rh blood group also called Rhesus system. It is encoded by the three genes C, D and E. The red blood cells in Rh system contain another antigen which is called Rd. antigen. It may be positive or negative. If it is present, then blood group will be Rd. positive but if it is absent then blood group will be Rd. negative. Hence, there will be eight blood groups such as A Rd. positive (A+), A Rd. negative (A-), B Rd. positive (B+), B Rd. negative (B-), O Rd. positive (O+), O Rd. negative (O-) [2]. Both these blood group systems were discovered by Landsteiner and used in blood transfusion and determination of parentage.
Hair is a protein which grows from the follicle present in dermis. It is very important biomaterial made up of protein called alpha keratin. Different varieties of hair textures are present but three most important are curl pattern, volume and consistency. According to some scientist's shape of hair shaft determine hair texture i.e. either they are straight or curly. If hair shaft is round, then straight hair grows but if it is flatter then curly hair grow. Hair volume may be thin, normal or thick. In hair consistency, fine hair has smallest circumference, coarse hair has largest circumference while medium hair has circumference between these two. According to Andre Walker system, there are 4 types of hair. Curly, straight, wavy and kinky. Curly hair has "S" shape, depend on climate and can easily be damaged. Straight hair has beautiful and flexible hair texture. It becomes difficult to curl them. Wavy hair is between straight and curly hair. Kinky hair type is fragile and has tightly coiled curl. When they are wet, they shrink. Objective of present studies was to correlates blood grouping with hair texture.

\section{Materials and Method \\ Blood Grouping}

First of all, took needle and prick on the upper portion of finger for blood extraction. After this took a slide and add three drops of blood and 3 drops of anti-sera A, B and D on that slide. Anti-sera A 
and anti-sera B was used to check the blood type while anti-sera D was used to check the positivity or negativity of that type. Those anti-sera that showed precipitate formation would show our blood group type.

\section{Project Designing}

A survey among subjects of different blood groups to determine their hair texture was performed. Each subject told either they had curly or straight hair with his consent. Total 181 subjects participated in present study. The subjects were students in Bahaudin Zakariya University Multan, Pakistan.

\section{Statistical Analysis}

Statistical analysis was performed by using MS Excel.

\section{Results and Discussion}

Blood group influence on hair texture is given in Table 1. Questionnaire based studies had given an important advancement in recent researches. Similar researches were also done by $S$ Miyasaka et al from Forensic Science Institute in May-Jun 1987 and L Potsch-Schneider et al. Z Rechtsmed 1986 [3-10].

Table 1.

\begin{tabular}{|c|c|c|c|c|}
\hline & \multicolumn{2}{|c|}{ Straight } & \multicolumn{2}{c|}{ Curly } \\
\hline $\begin{array}{c}\text { Blood } \\
\text { groups }\end{array}$ & Male & Female & Male & Female \\
\hline $\mathrm{A}+$ & $6.07 \%$ & $7.73 \%$ & $1.10 \%$ & $3.31 \%$ \\
\hline $\mathrm{A}-$ & $0.55 \%$ & $0 \%$ & $0 \%$ & $0.55 \%$ \\
\hline $\mathrm{B}+$ & $4.41 \%$ & $19.33 \%$ & $1.65 \%$ & $9.39 \%$ \\
\hline $\mathrm{B}-$ & $1.10 \%$ & $1.65 \%$ & $0 \%$ & $0 \%$ \\
\hline $\mathrm{AB}+$ & $1.65 \%$ & $3.86 \%$ & $0 \%$ & $0.55 \%$ \\
\hline $\mathrm{AB}-$ & $0 \%$ & $0.55 \%$ & $0 \%$ & $0 \%$ \\
\hline $\mathrm{O}+$ & $8.28 \%$ & $16.02 \%$ & $2.20 \%$ & $4.41 \%$ \\
\hline $\mathrm{O}-$ & $0 \%$ & $3.31 \%$ & $0 \%$ & $2.20 \%$ \\
\hline
\end{tabular}

\section{Conclusion}

It was concluded from present study that females having $\mathrm{B}+$ blood group have maximum straight hair while A- subjects (males and females), B- subjects (males \& females), $\mathrm{AB}+$ males, $\mathrm{AB}-$ subjects (males and females), 0 - males have minimum curly hair. Similarly, AB- and O- males have minimum straight hair.

\section{References}

1. Qadir MI, Malik SA (2010) Comparison of alterations in red blood cell count and alterations in hemoglobin concentration in patients suffering from rectal carcinoma undergoing 5-fluorouracil and folic acid therapy. Pharmacology online 3: 240-243.

2. Qadir MI, Noor A (2018) Anemias. Rare \& Uncommon Diseases. Cambridge Scholars Publishing. Newcastle, England.

3. Qadir MI, Javid A (2018) Awareness about Crohn's Disease in biotechnology students. Global Advanced Research Journal of Medicine and Medical Sciences 7(3): 062-064.

4. Qadir MI, Saleem A (2018) Awareness about ischemic heart disease in university biotechnology students. Global Advanced Research Journal of Medicine and Medical Sciences 7(3): 059-061.

5. Qadir MI, Ishfaq S (2018) Awareness about hypertension in biology students. Int J Mod Pharma Res 7(2): 08-10.

6. Qadir MI, Mehwish (2018) Awareness about psoriasis disease. Int J Mod Pharma Res 7(2): 17-18.

7. Qadir MI, Shahzad R (2018) Awareness about obesity in postgraduate students of biotechnology. Int J Mod Pharma Res 7(2): 14-16.

8. Qadir MI, Rizvi M (2018) Awareness about thalassemia in post graduate students. MOJ Lymphology \& Phlebology 2(1): 14-16.

9. Qadir MI, Ghalia BA (2018) Awareness survey about colorectal cancer in students of M. Phil Biotechnology at Bahauddin Zakariya University, Multan, Pakistan. Novel Approaches in Cancer Study 1(3).

10. Qadir MI, Saba G (2018) Awareness about intestinal cancer in university student. Novel Approaches in Cancer Study 1(3).

(C) 9 BY This work is licensed under Creative

To Submit Your Article Click Here: Submit Article

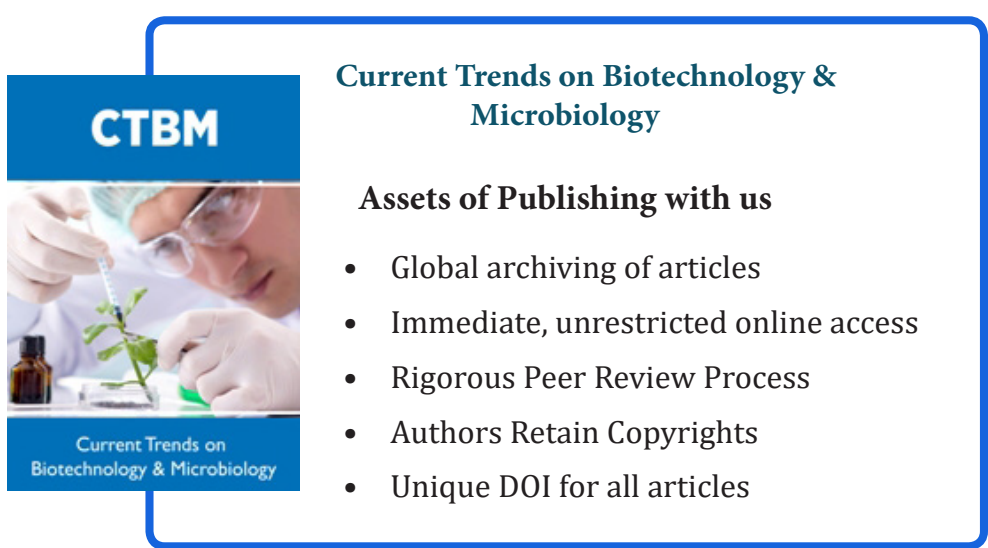

